\title{
Leptin Constrains Acetylcholine-induced Insulin Secretion from Pancreatic Islets of ob/ob Mice
}

\author{
Neng-Guin Chen, ${ }^{\star}$ Andrew G. Swick, ${ }^{\ddagger}$ and Dale R. Romsos* \\ $*$ Department of Food Science and Human Nutrition, Michigan State University, East Lansing, Michigan 48824-1224; and ${ }^{\ddagger}$ Department of \\ Metabolic Diseases, Pfizer Central Research, Groton, Connecticut 06340
}

\begin{abstract}
Hypersecretion of insulin from the pancreas is among the earliest detectable metabolic alterations in some genetically obese animals including the ob/ob mouse and in some obesity-prone humans. Since the primary cause of obesity in the ob/ob mouse is a lack of leptin due to a mutation in the ob gene, we tested the hypothesis that leptin targets a regulatory pathway in pancreatic islets to prevent hypersecretion of insulin. Insulin secretion is regulated by changes in blood glucose, as well as by peptides from the gastrointestinal tract and neurotransmitters that activate the pancreatic islet adenylyl cyclase (e.g., glucagon-like peptide-1) and phospholipase C (PLC) (e.g., acetylcholine) signaling pathways to further potentiate glucose-induced insulin secretion. Effects of leptin on each of these regulatory pathways were thus examined. Leptin did not influence glucose or glucagon-like peptide-1-induced insulin secretion from islets of either ob/ob or lean mice, consistent with earlier findings that these regulatory pathways do not contribute to the early-onset hypersecretion of insulin from islets of ob/ob mice. However, leptin did constrain the enhanced PLCmediated insulin secretion characteristic of islets from ob/ob mice, without influencing release from islets of lean mice. A specific enhancement in PLC-mediated insulin secretion is the earliest reported developmental alteration in insulin secretion from islets of ob/ob mice, and thus a logical target for leptin action. This action of leptin on PLC-mediated insulin secretion was dose-dependent, rapid-onset (i.e., within $3 \mathrm{~min}$ ), and reversible. Leptin was equally effective in constraining the enhanced insulin release from islets of ob/ob mice caused by protein kinase $\mathrm{C}$ (PKC) activation, a downstream mediator of the PLC signal pathway. One function of leptin in control of body composition is thus to target a PKC-regulated component of the PLC-PKC signaling system within islets to prevent hypersecretion of insulin. ( $J$. Clin. Invest. 1997. 100:1174-1179.) Key words: phospholipase $\mathrm{C} \cdot$ protein kinase $\mathrm{C} \cdot$ glucagon-like peptide-1
\end{abstract}

Address correspondence to Dale R. Romsos, Department of Food Science and Human Nutrition, Michigan State University, East Lansing, MI 48824-1224. Phone: 517-353-9511; FAX: 517-353-8963; E-mail: dromsos@msu.edu

Received for publication 13 March 1997 and accepted in revised form 9 June 1997.

J. Clin. Invest.

(C) The American Society for Clinical Investigation, Inc. 0021-9738/97/09/1174/06 \$2.00

Volume 100, Number 5, September 1997, 1174-1179

http://www.jci.org

\section{Introduction}

Leptin, the ob gene product secreted from adipocytes, controls adiposity by modulating food intake and energy metabolism (1-5). Leptin is thought to exert these functions by entering the brain and activating one of the variably spliced isoforms of the leptin receptor within the hypothalamus $(6,7)$, the brain region that integrates signals from the periphery to regulate body weight (8). Isoforms of the leptin receptor are also expressed in other organs including the pancreas, liver, and lung $(6,9-12)$. This suggests that leptin may also have direct physiological functions outside of the central nervous system.

Several lines of evidence support a possible role for leptin in regulation of insulin secretion from pancreatic islets. Mice and rats with sustained experimental hyperleptinemia (via exogenous leptin administration or leptin gene therapy) have lower plasma insulin concentrations than can be explained by the leptin-induced lowering of food intake $(13,14)$. In contrast, mice deficient in leptin, i.e., ob/ob mice with a mutation in the gene encoding leptin (15), develop hyperinsulinemia as early as $2 \mathrm{wk}$ of age, and before they begin to overeat or to develop insulin resistance or observable obesity (16-18). Leptin receptors are present within pancreatic islets (10-12), providing evidence that these in vivo effects of leptin excess or deficiency on plasma insulin concentrations might be mediated by direct actions of leptin on pancreatic islets. Finally, leptin has been reported to inhibit both basal and glucose-stimulated insulin release from the perfused pancreas or isolated pancreatic islets of ob/ob mice (11). But in another report (12), leptin failed to affect glucose-stimulated release of insulin from the pancreas of rats.

Hypersecretion of insulin from the pancreas is among the earliest detectable alterations in leptin-deficient ob/ob mice (18). Interestingly, islets from these young ob/ob mice initially exhibit normal insulin secretion in response to glucose $(18,19)$ even though they lack leptin. Only later in life is glucose-induced insulin secretion enhanced. This implies that regulatory steps in glucose-induced insulin secretion are altered secondary to other regulatory pathways, and that glucose-induced insulin secretion may not be a direct target for leptin action. Before the onset of hyperresponsiveness to glucose, islets from young ob/ob mice exhibit a specific enhancement in insulin secretion in the presence of acetylcholine $(18,19)$. Acetylcholine via stimulation of phospholipase C (PLC) ${ }^{1}$ generates diacylglycerol which activates protein kinase $\mathrm{C}$ (PKC) $(20,21)$. This PKC signaling pathway is altered in islets from ob/ob mice (19, 22 ), raising the possibility that leptin might specifically target this regulatory pathway to control insulin secretion. Islets from $\mathrm{ob} / \mathrm{ob}$ mice were thus incubated in the presence or absence of leptin to test this possibility.

1. Abbreviations used in this paper: GLP-1, glucagon-like peptide-1; PKC, protein kinase C; PLC, phospholipase; PMA, phorbol-12-myristate-13-acetate. 


\section{Methods}

Female ob/ob mice and lean littermates $(\mathrm{ob} /+$ or $+/+)$ from our breeding colony $(\mathrm{C} 57 \mathrm{BL} / 6 \mathrm{~J}-\mathrm{ob} /+$ ) were used at $4 \mathrm{wk}$ of age (except for one study with 2 -wk-old mice and a second with 8 -wk-old mice, as indicated in the text and Fig. 1). Mice were housed at $25^{\circ} \mathrm{C}$ with a $12 \mathrm{~h}$ light-dark cycle (lights on at $0700 \mathrm{~h}$ ) and were fed a nonpurified diet (Tekland Laboratory Diet 8640; Harlan, Inc., Bartonville, IL). Their care was in accordance with Michigan State University guidelines.

Murine and human ob cDNAs were subcloned into pET15b and expressed in Escherichia coli BL21(DE3). Histidine-tagged recombinant murine and human leptins were isolated. The histidine tag was removed by thrombin cleavage and the proteins were refolded and monomeric leptins were isolated by anion exchange. The final preparations were greater than $98 \%$ pure and were tested for endotoxin. Murine leptin was used in the study with 2-wk-old mice, and human leptin was used in all the other studies.

Islets from mice in the fed state were isolated as described previously $(23,24)$ and cultured (19) overnight (islets from 2-wk-old mice were cultured $4 \mathrm{~d}$ ) in serum-free RPMI 1640 medium (10 mM glucose) before incubation in Krebs-Ringer bicarbonate buffer to measure insulin secretion. Islets were cultured before study to diminish the possibility that residue leptin from the in vivo environment of lean mice would directly influence insulin secretion from isolated islets. Islets were either incubated statically (10 islets per petri dish) or perifused (20 islets per chamber, flow rate of $0.4 \mathrm{ml} / \mathrm{min}$ ) as described previously $(18,19)$. Insulin was measured by an ELISA procedure (18). An islet preparation from a mouse was used in only a single experiment.

\section{Results}

Basal rates of insulin secretion from islets of 2-wk-old ob/ob and lean mice incubated in $0.5-\mathrm{mM}$ glucose were low and similar; values $(n=3)$ averaged $0.50 \pm 0.02$ and $0.51 \pm 0.01$ femtomol islet ${ }^{-1} \cdot \mathrm{min}^{-1}$ in islets from ob/ob and lean mice, respectively. Insulin secretion increased equally from islets of ob/ob and lean mice during a $30-\mathrm{min}$ exposure to $10-\mathrm{mM}$ glucose;

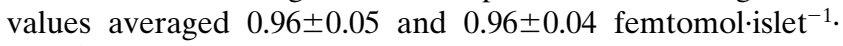
$\mathrm{min}^{-1}$ in islets from these 2 -wk-old ob/ob and lean mice, respectively. These results confirm earlier reports that islets from 2-wk-old ob/ob mice respond normally to glucose, even though they are already slightly hyperinsulinemic at this age $(17,18)$. Addition of a high concentration of leptin $(1-\mu \mathrm{M}$ murine leptin) to islets incubated in $10-\mathrm{mM}$ glucose tended to lower insulin secretion, but the effect was not statistically significant (ANOVA, $P>0.05)$. Values $(n=3)$ averaged $0.82 \pm 0.04$ and $0.89 \pm 0.03$ femtomol $\cdot$ islet $^{-1} \cdot \mathrm{min}^{-1}$ from islets of 2-wk-old ob/ob and lean mice, respectively, during the 30-min incubation. Since only a limited number of mice were used in this study, we repeated the study, but with older mice. Islets from the 4- and 8-wk-old mice used were incubated in $20-\mathrm{mM}$ glucose to maximally stimulate glucose-induced insulin secretion. At these ages, islets from ob/ob mice secrete more insulin in response to glucose than islets from lean mice (Fig. 1). We reasoned that these conditions would optimize the potential for leptin to inhibit glucose-induced insulin secretion. However, addition of leptin failed to constrain either glucoseinduced hypersecretion of insulin from islets of these ob/ob mice or insulin secretion from islets of the lean mice (Fig. 1). Likewise, pretreatment of islets from 4-wk-old ob/ob and lean mice with $20 \mathrm{nM}$ leptin for $18 \mathrm{~h}$ did not influence glucoseinduced insulin secretion. At the end of the 18-h period, glucose $(10 \mathrm{mM})$-induced insulin secretion averaged $3.4 \pm 0.4$ and

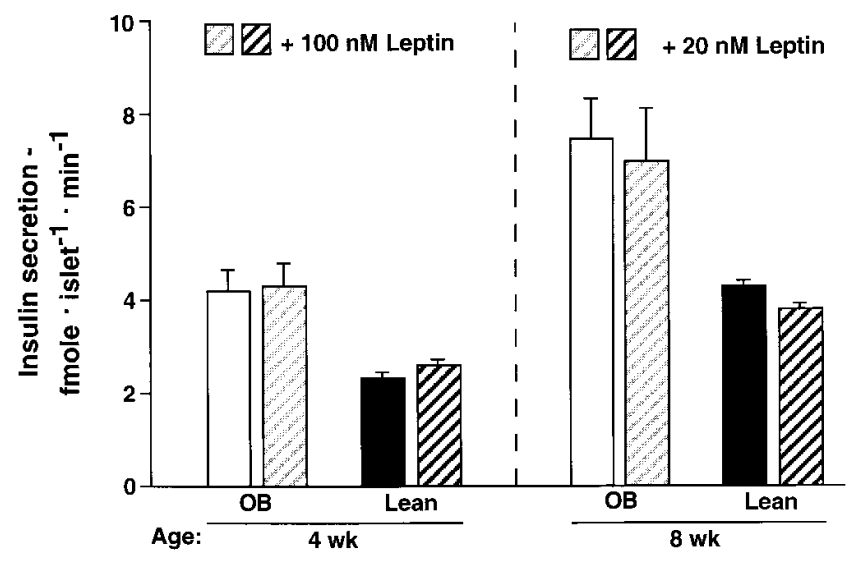

Figure 1. Glucose-induced insulin secretion from islets exposed to leptin. Islets (10 islets per group) were preincubated in $0.5-\mathrm{mM}$ glucose for $60 \mathrm{~min}$. Islets from 4 -wk-old ob/ob and lean mice secreted $0.5 \pm 0.05$ and $0.5 \pm 0.04$ femtomol $(\mathrm{fmol}) \cdot$ islet $^{-1} \cdot \mathrm{min}^{-1}$, respectively, and islets from 8 -wk-old ob/ob and lean mice secreted $0.9 \pm 0.03$ and $0.8 \pm 0.04 \mathrm{fmol} \cdot$ islet $^{-1} \cdot \mathrm{min}^{-1}$, respectively, in $0.5-\mathrm{mM}$ glucose. Islets were then incubated with $20-\mathrm{mM}$ glucose $\pm 100-\mathrm{nM}$ human leptin (4-wk-old mice) or \pm 20 -nM human leptin (8-wk-old mice) for $30 \mathrm{~min}$. Each bar represents mean \pm SEM for 6-8 mice. Phenotype, but not leptin, influenced insulin secretion at each age as determined by twoway ANOVA $(P<0.05)$.

$3.0 \pm 0.5$ femtomol $\cdot$ islet ${ }^{-1} \cdot \mathrm{min}^{-1}$ from islets of ob/ob mice pretreated without and with $20-\mathrm{nM}$ leptin, respectively, and $1.2 \pm 0.2$ and $1.4 \pm 0.2 \mathrm{femtomol} \cdot \mathrm{islet}^{-1} \cdot \mathrm{min}^{-1}$ from islets of lean mice pretreated without and with 20-nM leptin, respectively.

Glucagon-like peptide-1, a potent incretin secreted from intestinal cells in response to oral glucose, activates adenylyl cyclase and the downstream protein kinase A signal transduction pathway in pancreatic B cells to enhance glucose-induced insulin secretion $(25,26)$. Leptin also failed to influence the glucagon-like peptide-1 stimulation of glucose-induced insulin secretion from islets of either 4-wk-old ob/ob or lean mice (Fig. 2), suggesting that leptin does not directly influence either the glucose-mediated or the protein kinase A-mediated regulatory pathways in insulin secretion.

Acetylcholine, via activation of muscarinic receptors and subsequent stimulation of the PLC signal transduction pathway, enhances insulin secretion more from islets of young ob/ ob mice than from islets of lean mice $(18,19)$. This is the earliest reported developmental alteration in an insulin secretory regulatory pathway in islets of ob/ob mice, occurring at 2 wk of age and coincidental with the onset of hyperinsulinemia (16, $18,19)$. Cholecystokinin also stimulates the PLC signal transduction pathway $(20,21,27)$ and causes more insulin release from islets of ob/ob mice than lean mice (18). The neurotransmitter acetylcholine and the gastrointestinal peptide cholecystokinin likely activate a common PLC-mediated step to cause hypersecretion of insulin from islets of young ob/ob mice (18). Since these ob/ob mice are deficient in leptin (14), we hypothesized that leptin targets this regulatory pathway. Thus, islets from 2-wk-old ob/ob and lean mice were incubated for $30 \mathrm{~min}$ with $10-\mathrm{mM}$ glucose, and $10-\mu \mathrm{M}$ acetylcholine $\pm 1 \mu \mathrm{M}$ murine leptin. As expected $(17,18)$, islets from these 2-wk-old ob/ob mice exposed to acetylcholine secreted more insulin (6.4 \pm 0.6 femtomol.islet $\left.{ }^{-1} \cdot \mathrm{min}^{-1}\right)$ than islets from lean mice $(1.9 \pm 0.1$ 


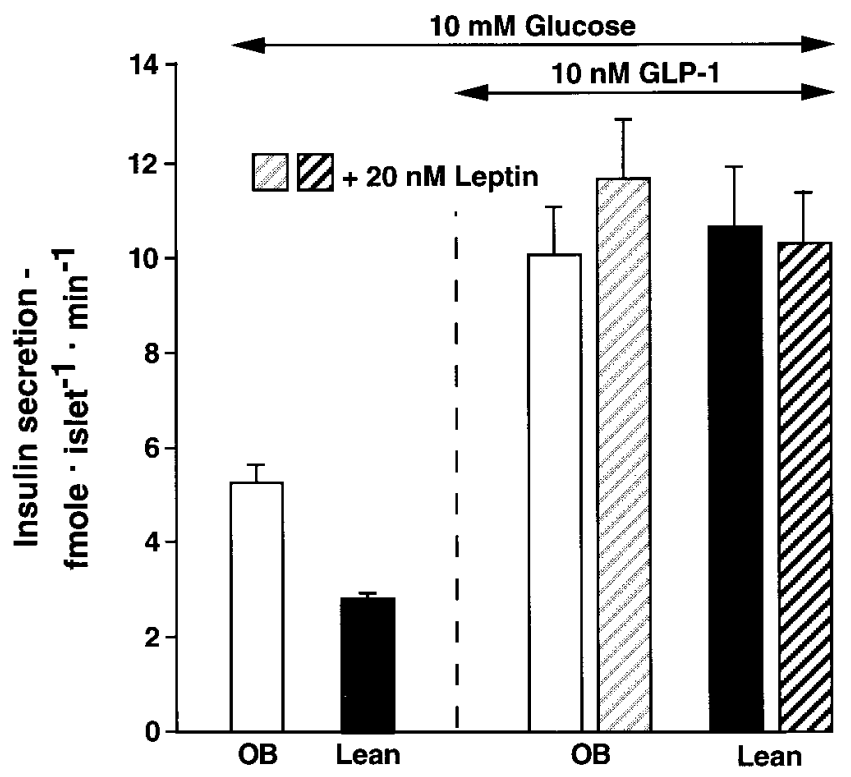

Figure 2. Effects of leptin on human synthetic glucagon-like peptide-1 (GLP-1, 7-36 amide)-induced insulin secretion. Islets from 4-wk-old ob/ob mice and their lean counterparts $(n=6-7)$ were prepared and incubated with $10-\mathrm{mM}$ glucose for $30 \mathrm{~min}$ before addition of GLP-1 1 leptin for an additional $30 \mathrm{~min}$. Islets from ob/ob mice incubated with $10-\mathrm{mM}$ glucose alone secreted more insulin than islets from lean mice as determined by the paired student's $t$ test $(P<0.05)$. Neither phenotype nor leptin influenced GLP-1-induced insulin secretion as determined by two-way ANOVA.

femtomol $\cdot$ islet $\left.^{-1} \cdot \mathrm{min}^{-1}\right)(n=3, P<0.05)$, even though rates of glucose-induced insulin secretion from these islets were unaffected by phenotype (see first paragraph of Results for data). Addition of $1-\mu \mathrm{M}$ murine leptin totally prevented the excess PLC-mediated insulin secretion from islets of these 2-wk-old ob/ob mice $\left(1.9 \pm 0.1\right.$ femtomol $\cdot$ islet $\left.^{-1} \cdot \mathrm{min}^{-1}\right)$ versus lean mice $\left(1.7 \pm 0.1 \mathrm{femtomol} \cdot\right.$ islet $\left.^{-1} \cdot \mathrm{min}^{-1}\right)$, without influencing insulin secretion from islets of lean mice. Consistent with these results, 20-nM human leptin totally prevented the excess PLCmediated insulin secretion from islets of 4-wk-old ob/ob mice versus lean mice, without any detectable influence of leptin on islets from lean mice (Fig. 3). PKC is a downstream mediator of PLC activation (28-30). Direct activation of PKC with an agonist (0.1- $\mu \mathrm{M}$ phorbol-12-myristate-13-acetate, PMA) mimics the effects of acetylcholine on insulin secretion from islets from ob/ob and lean mice $(18,19)$ (Fig. 3). Again, leptin totally prevented the excess $\mathrm{PKC}$-induced secretion characteristic of the islets from ob/ob mice without influencing insulin secretion from islets of lean mice (Fig. 3). Since the same doses and preparations of leptin failed to influence either the glucosemediated or the protein kinase A-mediated pathways of insulin secretion, we conclude that leptin directly targets the PLC$\mathrm{PKC}$ regulatory pathway to constrain insulin secretion.

Leptin at concentrations as low as $2.5 \mathrm{nM}$ partially constrained acetylcholine-induced insulin secretion from islets of ob/ob mice, with an $\mathrm{IC}_{50}$ effective concentration of $\sim 5 \mathrm{nM}$ (Fig. 4). Thus, the concentration of leptin required to regulate a physiological process in islets (i.e., insulin secretion) is in the same general range (i.e., nanomolar) as the reported $\mathrm{IC}_{50}$ for specific leptin binding to a hypothalamic membrane preparation (i.e., $46 \mathrm{nM}$ ) (31). Islets from mice are also now known to

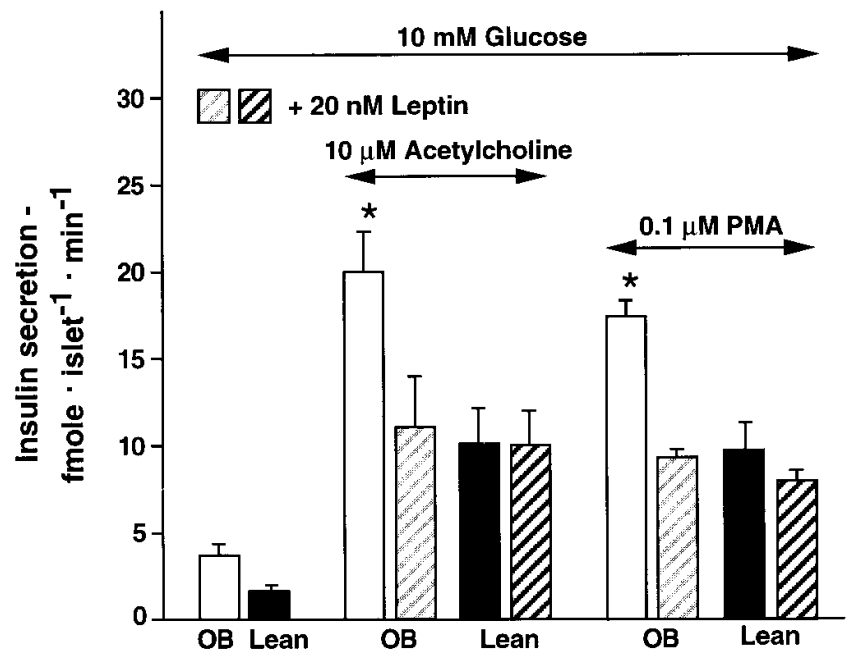

Figure 3. Effects of leptin on acetylcholine and PKC-induced insulin secretion. Islets from 4-wk-old ob/ob mice and their lean counterparts $(n=5)$ were prepared and incubated with $10-\mathrm{mM}$ glucose for $30 \mathrm{~min}$ before addition of acetylcholine \pm leptin, or a PKC agonist (phorbol12-myristate-13-acetate, $P M A) \pm$ leptin, for an additional $30 \mathrm{~min}$. Islets from ob/ob mice incubated with $10-\mathrm{mM}$ glucose secreted more insulin than islets from lean mice as determined by the paired Student's $t$ test $(P<0.05)$. Significant $(P<0.05)$ phenotype, leptin, and phenotype-leptin interaction effects on insulin secretion were present in islets exposed to acetylcholine or to 0.1- $\mu \mathrm{M}$ PMA, as determined by two-way ANOVA in conjunction with Bonferroni adjustment. *Significant difference $(P<0.05)$ from other groups treated with $10-\mu \mathrm{M}$ acetylcholine or $0.1-\mu \mathrm{M}$ PMA.

contain leptin receptor mRNA (11). Concentrations of leptin sufficient to activate receptors within the hypothalamus to control food intake would seem equally likely to activate the leptin signal transduction system in pancreatic islets to control insulin release.

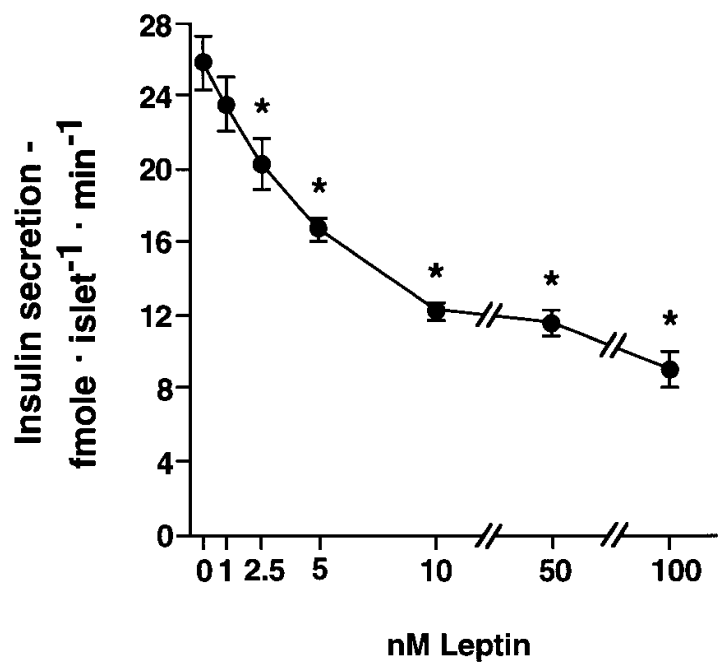

Figure 4. Leptin dose-response inhibition of acetylcholine-induced insulin secretion. Islets from 4-wk-old ob/ob mice $(n=6-8$ at each point) were prepared and incubated in $10-\mathrm{mM}$ glucose, $10-\mu \mathrm{M}$ acetylcholine and 0-100 $\mathrm{nM}$ leptin. Islets exposed to leptin at doses $\geq 2.5$ nM secreted less insulin $(P<0.05)$, as determined by one-way ANOVA in conjunction with Bonferroni adjustment. 


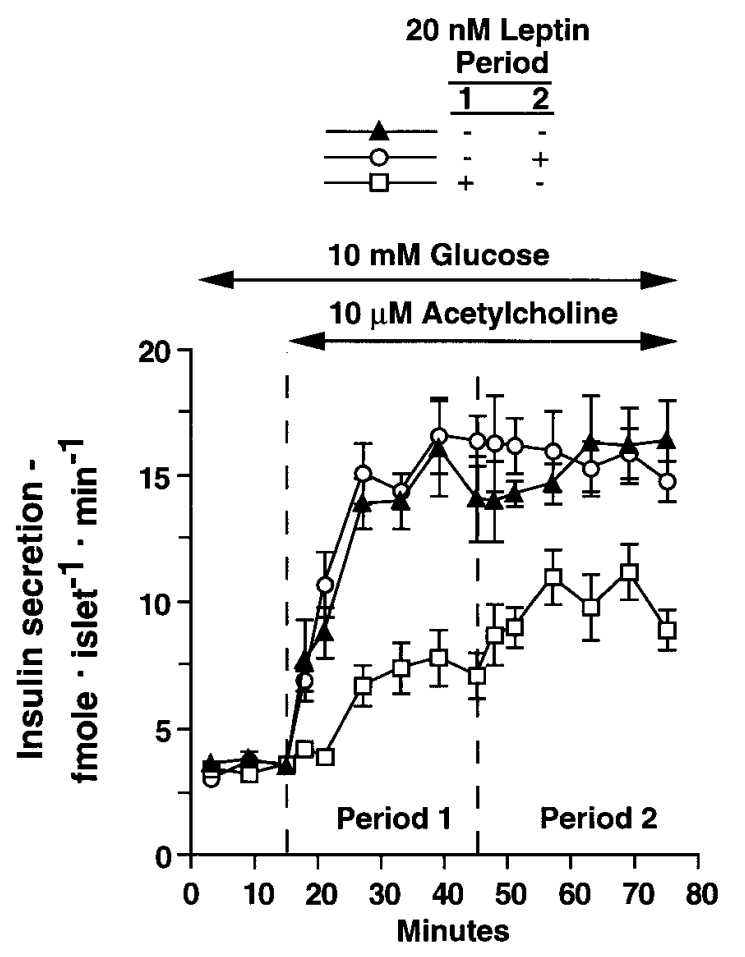

Figure 5. Time course effects of leptin on acetylcholine-induced insulin secretion. Islets from 4-wk-old ob/ob mice $(n=6)$ were prepared and perifused (20 islets per chamber) with $10-\mathrm{mM}$ glucose before addition of acetylcholine \pm leptin for two consecutive 30-min periods as indicated in the figure. Samples were collected at 3-min intervals. Islets treated with acetylcholine and leptin simultaneously in Period 1 secreted less $(P<0.05)$ insulin than those exposed to acetylcholine alone, with the lower rates of secretion continuing even after leptin was removed (Period 2, $\square$ ). Exposure of islets to acetylcholine for $30 \mathrm{~min}$ in Period 1 in the absence of leptin abolished the subsequent ability of leptin to affect acetylcholine-induced insulin secretion in Period $2(P>0.05)$ as determined by two-way ANOVA in conjunction with Bonferroni adjustment.

Islets from ob/ob mice were perifused to determine the time course for the onset and reversal of leptin action on acetylcholine-induced insulin secretion. Leptin blocked the immediate (i.e., within $3 \mathrm{~min}$ ) increase in insulin secretion resulting from addition of acetylcholine (Fig. 5, Period 1), and limited acetylcholine-induced secretion during the $30-\mathrm{min}$ period to about half of the rate that occurred in the absence of leptin, consistent with findings in statistically incubated islets from ob/ ob mice (Fig. 3). Removal of leptin from the perifusate during the second 30 -min period caused only a moderate $35 \%$ increase in acetylcholine-induced insulin secretion (Fig. 5, Period 2). Leptin was ineffective when added after pre-established, acetylcholine-induced hypersecretion of insulin was present (Fig. 5, Period 2).

To further explore the time course for the reversal of leptin action on acetylcholine-induced insulin secretion, islets from ob/ob mice were pretreated for up to $18 \mathrm{~h}$ in 20 -nM leptin, leptin was then removed for $1.5-6 \mathrm{~h}$ before exposure to acetylcholine. Removal of leptin for $1.5 \mathrm{~h}$ caused a subsequent $38 \%$ increase in acetylcholine-induced insulin secretion (Fig. 6, Treatments 3 and 4 versus 2), a response similar to that observed within minutes after leptin was withdrawn from peri-



Figure 6. Time course of the reversal of leptin inhibition of acetylcholine-induced insulin secretion. Freshly-isolated islets from 4-wk-old ob/ob mice $(n=5-6)$ were cultured overnight in serum-free, RPMI 1640 medium (10-mM glucose) \pm 20 -nM leptin for varying lengths of time. All islets were then washed three times in KrebsRinger bicarbonate buffer containing $10-\mathrm{mM}$ glucose and incubated for $1.5 \mathrm{~h}$ before addition of $10-\mathrm{mM}$ glucose and $10-\mu \mathrm{M}$ acetylcholine for a 0.5 -h period. Two control groups of islets were used; Treatment 1 served as a negative control without exposure to leptin, and Treatment 2 served as a positive control with simultaneous exposure to acetylcholine and leptin (i.e., $0-0.5 \mathrm{~h}$ ). Islets in Treatments 3 and 4 were pretreated with leptin for $0.5 \mathrm{~h}$ (i.e., -2.0 to $-1.5 \mathrm{~h}$ ) and $18 \mathrm{~h}$ (i.e., -19.5 to $-1.5 \mathrm{~h}$ ), respectively, ending $1.5 \mathrm{~h}$ before exposure to acetylcholine. Islets in Treatment 5 were pretreated with leptin for $18 \mathrm{~h}$ (i.e., -24.0 to $-6.0 \mathrm{~h}$ ) ending $6 \mathrm{~h}$ before exposure to acetylcholine; these islets were washed in leptin-free RPMI 1640 medium and then maintained for $4.5 \mathrm{~h}$ before washing in Krebs-Ringer bicarbonate buffer and incubating for $1.5 \mathrm{~h}$ as indicated above. *Significant effect of leptin $(P<0.05)$ on acetylcholine-induced insulin secretion as indicated by one-way ANOVA in conjunction with Bonferroni adjustment.

fused islets (Fig. 5). One component of the inhibitory effect of leptin on insulin secretion is thus rapidly reversible, but significant suppression of acetylcholine-induced insulin release still persists during this 1.5 -h period. Full reversal of leptin action occurred when the time between exposure to leptin and subsequent addition of acetylcholine was extended to $6 \mathrm{~h}$ (Fig. 6, Treatments 5 and 1).

\section{Discussion}

We found that leptin uniquely targeted a specific regulatory component of the PLC/PKC-induced insulin secretion pathway within islets from ob/ob mice to constrain insulin secretion. This action of leptin on insulin secretion was rapid-onset (i.e., within $3 \mathrm{~min}$ ), reversible, and dose-dependent. Effects of leptin were demonstrable only in islets from ob/ob mice with 
characteristic hypersecretion of insulin, not in islets from lean mice, suggesting that leptin functions within pancreatic islets primarily to prevent hypersecretion of insulin.

Based on the observations that the earliest detectable alteration in insulin secretion from islets of ob/ob mice and fa/fa rats (animals with a deficiency in leptin or leptin resistance secondary to a mutation in the leptin receptor) is an enhanced insulin secretion response to acetylcholine $(18,19,32)$, it seemed reasonable to speculate that leptin would directly or indirectly influence this regulatory pathway. Consistent with this, leptin specifically targeted the PLC-PKC-mediated regulatory component of insulin secretion rather than the glucose or protein kinase A signaling components of the secretory process. Leptin did not block PLC-PKC-induced insulin secretion totally, but rather uniquely inhibited the hyperactive component of this pathway without interfering with normal responsiveness of islets to PLC activation. It inhibited the hyperactivity of the PLC-PKC pathway by preventing the activation of PKC-regulated steps in insulin secretion, as opposed to reducing preactivated PKC-regulated insulin secretion. This conclusion is based on the finding that leptin was effective only when given before or in conjunction with acetylcholine, but not when leptin addition followed the activation of the PLC-PKC pathway.

We cannot at this time explain why an earlier report (11) showed that 10-100-nM murine leptin inhibited glucose-induced insulin secretion from islets of ob/ob mice. The fact that leptin inhibited basal as well as glucose-induced insulin secretion in their study might imply a generalized overall suppressive effect of leptin on insulin secretion. But if leptin acts via a pathway that inhibits the overall secretory response, or even primarily by a pathway that targets glucose-induced insulin secretion, the leptin-deficient ob/ob mouse should exhibit enhanced glucose-induced insulin secretion as an initial developmental event. However, this does not occur. Rather, an enhanced insulin secretion response to acetylcholine precedes the enhanced response to either glucose or protein kinase A in leptin-deficient ob/ob mice $(18,19)$. Consistent with these observations, we found that leptin targeted the acetylcholine, PLC-PKC-mediated pathway. We conclude that this pathway is a primary site for leptin action in pancreatic islets. However, it remains possible that this action of leptin also has secondary effects on other components of the insulin secretion regulatory pathway in certain circumstances.

Pancreatic islets from ob/ob and lean mice express the fulllength leptin receptor proposed to participate in signal transduction (11). This receptor is homologous to members of the cytokine receptor superfamily and recently has been shown to activate several members of the signal transducers and activators of transcription (STAT) family (33). This activation may involve association of janus kinases (JAK) with the activated leptin receptor to cause phosphorylation of STAT (33). The rapid onset of leptin action in islets to prevent enhanced PLCPKC-induced insulin secretion (i.e., within $3 \mathrm{~min}$ ) would seem to preclude a direct role for leptin-mediated gene transcription in this process. Analogous rapid onset effects of leptin have been reported recently in the hypothalamus where leptin modulates synaptic transmission within a time frame of minutes (34). Glaum et al. (34) postulated that leptin may exert rapid effects via JAK-regulated phosphorylation of regulatory proteins. Consistent with this, leptin has been shown recently to rapidly reduce the phosphorylation state of insulin receptor substrate-1 in HepG2 cells (35). Inactivation of the leptin re- ceptor signaling pathway responsible for regulating insulin secretion requires several hours whereas activation of the pathway occurs within minutes. Possibly leptin only slowly dissociates from the receptor or alternatively the downstream signaling pathway is only slowly inactivated.

Leptin did not influence insulin secretion from islets of our lean mice. This observation is supported by data from islets of the ob/ob mice where leptin only returned PLC-PKC-stimulated insulin secretion to normal. Leptin did not lower insulin secretion from islets of ob/ob mice below rates observed from islets of lean mice. It appears that islets from ob/ob mice possess a unique, leptin-responsive, PLC-PKC-regulated pathway. This pathway may be downregulated in islets from lean mice, probably because they, unlike islets from ob/ob mice, had been exposed to leptin in vivo. Since, in isolated islets from ob/ob mice, leptin action occurred rapidly (within minutes) and was reversed within several hours of leptin withdrawal, islets from lean mice cultured in the absence of leptin for $18 \mathrm{~h}$ might be expected to exhibit a leptin-inhibitable hypersecretion of insulin when subsequently exposed to acetylcholine. This did not occur. Even when maintained in culture for up to $12 \mathrm{~d}$, islets from ob/ob mice still hypersecrete insulin in response to acetylcholine versus responses in identically-treated islets from lean mice (19). Once established, this leptin-responsive component of the PLC-PKC-regulated insulin secretion pathway thus persists for relatively long periods in islets from ob/ob mice, and conversely this pathway is not readily expressed in islets from lean mice. Possibly, the presence or absence of leptin early in life programs pancreatic islets to either block the development of this unique leptin-responsive, PLC-PKC-regulated pathway or permit expression of the pathway.

The mechanism whereby leptin modulates PKC-regulated insulin secretion is not known presently. Activation of PKC within cells is a complex process that includes translocation of cytosolic PKC to membranes where it exhibits catalytic activity as well as involvement of PKC-binding proteins that may further target the activated enzyme to specific sites $(36,37)$. Leptin might, for example, regulate a component of this enzyme activation process by influencing the phosphorylation state of one or more of the involved proteins. There is a family of PKC isozymes with differential sensitivities to activation (36-39). Islets of ob/ob mice might also process a PKC isozyme pattern that is more responsive to leptin than islets of lean mice. Consistent with our speculation that leptin interferes with the activation of the PKC signal process, leptin did not constrain insulin secretion from islets when PKC was already activated by acetylcholine.

Identification of the components of the PKC-regulated pathway in islets affected by leptin will be important. Some obesity-prone humans may have an early onset-enhanced PLC stimulation of insulin secretion (40). It would be of interest to determine whether these subjects also have low plasma leptin concentrations, as appears to occur in a subset of obese subjects (41-43). Alternatively, perhaps the leptin resistance characteristic of many obese subjects will unmask the expression of a PLC-PKC induced hypersecretion of insulin.

\section{Acknowledgments}

We thank Boris A. Chrunyk and David Cunningham for providing purified leptin, Chris Oberg for preparation of the graphs, and Shelli Pfeifer for assistance with manuscript preparation. 
This work was supported by NIH DK-15847 and the Michigan Agricultural Experiment Station.

\section{References}

1. Pelleymounter, M.A., M.J. Cullen, M.B. Baker, R. Hecht, D. Winters, T. Boone, and F. Collins. 1995. Effects of the obese gene product on body weight regulation in ob/ob mice. Science (Wash. DC). 269:540-543.

2. Halaas, J.L., K.S. Gajiwala, M. Maffei, S.L. Cohen, B.T. Chait, D. Rabinowitz, R. Lallone, S.K. Burley, and J.M. Friedman. 1995. Weight-reducing effects of the plasma protein encoded by the obese gene. Science (Wash. DC). 269:543-546.

3. Campfield, L.A., F.J. Smith, Y. Guisez, R. Devos, and P. Burn. 1995. Recombinant mouse ob protein: evidence for a peripheral signal linking adiposity and central neural networks. Science (Wash. DC). 269:546-549.

4. Caro, J.F., M.K. Sinha, J.W. Kolaczynski, P.L. Zhang, and R.V. Considine. 1996. Leptin: the tale of an obesity gene. Diabetes. 45:1455-1462.

5. Campfield, L.A., F.J. Smith, and P. Burn. 1996. The OB protein (leptin) pathway-A link between adipose tissue mass and the central neural networks. Horm. Metab. Res. 28:619-632.

6. Tartaglai, L.A., M. Dembski, X. Weng, N. Deng, J. Culpepper, R. Devos, G.J. Richards, L.A. Campfield, F.T. Clark, J. Deeds, et al. 1995. Identification and expression cloning of a leptin receptor, Ob-R. Cell. 83:1263-1271.

7. Lee, G.H., R. Proenca, J.M. Montez, K.M. Carroll, J.G. Darvishzadeh, and J.I. Lee. 1996. Abnormal splicing of the leptin receptor in diabetic mice. Nature (Lond.). 379:622-635.

8. Luiten, P.G.M., G.J. ter Horst, and A.B. Steffens. 1987. The hypothalamus intrinsic connections and outflow pathways to the endocrine system in relation to the control of feeding and metabolism. Prog. Neurobiol. (Oxf.). 28:1-54.

9. Ghilardi, N., S. Ziegler, A. Wiestner, R. Stoffel, M.H. Heim, and R.C. Skoda. 1996. Defective STAT signaling by the leptin receptor in diabetic mice. Proc. Natl. Acad. Sci. USA. 93:6231-6235.

10. Kieffer, T.J., R.S. Heller, and J.F. Habener. 1996. Leptin receptors expressed in pancreatic $\beta$-cells. Biochem. Biophys. Res. Commun. 224:522-527.

11. Emilsson, V., Y.-L. Liu, M.A. Cawthorne, N.M. Morton, and M. Davenport. 1997. Expression of the functional leptin receptor mRNA in pancreatic islets and direct inhibitory action of leptin on insulin secretion. Diabetes. 46:313316 .

12. Leclercq-Meyer, V., R.V. Considine, A. Sener, and W.J. Malaisse. 1996. Do leptin receptors play a functional role in the endocrine pancreas? Biochem. Biophys. Res. Commun. 229:794-798.

13. Levin, N., C. Nelson, A. Gurney, R. Vandlen, and F. De Sauvage. 1996. Decreased food intake does not completely account for adiposity reduction after ob protein infusion. Proc. Natl. Acad. Sci. USA. 93:1726-1730.

14. Chen, G., K. Koyama, X. Yuan, Y. Lee, Y.-T. Zhou, R. O’Doherty, C.B. Newgard, and R.H. Unger. 1996. Disappearance of body fat in normal rats induced by adenovirus-mediated leptin gene therapy. Proc. Natl. Acad. Sci. USA. 93:14795-14799.

15. Zhang, Y., R. Proenca, M. Maffei, M. Barone, L. Leopold, and J.M. Friedman. 1994. Positional cloning of the mouse obese gene and its human homologue. Nature (Lond.). 372:425-432.

16. Dubuc, P.U. 1976. The development of obesity, hyperinsulinemia, and hyperglycemia in ob/ob mice. Metab. Clin. Exp. 25:1567-1574.

17. Lin, P.-Y., D.R. Romsos, and G.A. Leveille. 1977. Food intake, bodyweight gain, and body composition of the young obese (ob/ob) mouse. J. Nutr. 107:1715-1723.

18. Chen, N.-G., and D.R. Romsos. 1995. Enhanced sensitivity of pancreatic islets from preobese 2-week-old ob/ob mice to neurohormonal stimulation of insulin secretion. Endocrinology. 136:505-511.

19. Chen, N.-G., and D.R. Romsos. 1997. Persistently enhanced sensitivity of pancreatic islets from ob/ob mice to PKC-stimulated insulin secretion. Am.J. Physiol. 272 (Endocrinol. Metab. 35):E304-E311.

20. Prentki, M., and F.M. Matschinsky. 1987. $\mathrm{Ca}^{2-}$, cAMP and phospholipid-derived messengers in coupling mechanisms of insulin secretion. Physiol. Rev. 67:1185-1248.

21. Zawalich, W.S., and H. Rasmussen. 1990. Control of insulin secretion: a model involving $\mathrm{Ca}^{2-}$, cAMP and diacylglycerol. Mol. Cell. Endocrinol. 70:119-
137

22. Zawalich, W.S., and K.C. Zawalich. 1996. Signal transduction in isolated islets from the ob/ob mouse: enhanced sensitivity of protein kinase $\mathrm{C}$ to stimulation. Biochem. Biophys. Res. Commun. 223:618-623.

23. Lacy, P.E., and M. Kostianovsky. 1967. Method for the isolation of intact islets of Langerhans from the rat pancreas. Diabetes. 16:35-39.

24. Tassava, T.M., T. Okuda, and D.R. Romsos. 1992. Insulin secretion from ob/ob mouse pancreatic islets: effects of neurotransmitters. Am. J. Physiol. 262 (Endocrinol. Metab. 25):E338-E343.

25. Creutzfeldt, W., and R. Ebert. 1985. New developments in the incretin concept. Diabetologia. 28:565-573.

26. Gefel, D., G.K. Hendrick, S. Mojsov, J. Habener, and G.C. Weir. 1990. Glucagon-like peptide-1 analogs: effects on insulin secretion and adenosine 3', 5' monophosphate formation. Endocrinology. 126:2164-2168.

27. Schnefel, S., H. Banfic, L. Eckhardt, G. Schultz, and I. Schulz. 1988. Acetylcholine and cholecystokinin receptors functionally couple by different G-proteins to phospholipase C in pancreatic acinar cells. FEBS Lett. 230:125130.

28. Persaud, S.J., P.M. Jones, D. Sugen, and S.L. Howell. 1989. The role of protein kinase $\mathrm{C}$ in cholinergic stimulation of insulin secretion from rat islets of Langerhans. Biochem. J. 264:753-758.

29. Persaud, S.J., P.M. Jones, and S.L. Howell. 1993. Staurosporine inhibits protein kinases activated by $\mathrm{Ca}^{2-}$ and cyclic AMP in addition to inhibiting protein kinase C in rat islets of Langerhans. Mol. Cell. Endocrinol. 94:55-60.

30. Persaud, S.J., P.M. Jones, and S.L. Howell. 1992. The role of protein kinase $\mathrm{C}$ in insulin secretion. In Nutrient Regulation of Insulin Secretion. P.R. Flatt, editor. Portland Press Ltd., London. pp. 247-269.

31. Stephens, T.W., M. Basinski, P.K. Bristow, J.M. Bue-Valleskey, S.G. Burgett, L. Craft, J. Hale, J. Hoffman, H.M. Hsiung, A. Kriauciunas, et al. 1995. The role of neuropeptide $\mathrm{Y}$ in the antiobesity action of the obese gene product. Nature (Lond.). 377:530-532.

32. Atef, N., C. Brule, M. Bihoreau, and A. Ktorza. 1991. Enhanced insulin secretory response to acetylcholine by perifused pancreas of 5-day-old preobese Zucker rats. Endocrinology. 129:2219-2224.

33. Ghilardi, N., S. Ziegler, A. Wiestner, R. Stoffel, M.H. Heim, and R.C. Skoda. 1996. Defective STAT signaling by the leptin receptor in diabetic mice. Proc. Natl. Acad. Sci. USA. 93:6231-6235.

34. Glaum, S.R., M. Hara, V.P. Bindokas, C.C. Lee, K.S. Polonsky, G.I. Bell, and R.J. Miller. 1996. Leptin, the obese gene product, rapidly modulates synaptic transmission in the hypothalamus. Mol. Pharmacol. 50:230-235.

35. Cohen, B., D. Novick, and M. Rubinstein. 1996. Modulation of insulin activities by leptin. Science (Wash. DC). 274:1185-1188.

36. Nashizuka, Y. 1995. Protein kinase $\mathrm{C}$ and lipid signaling for sustained cellular responses. FASEB (Fed. Am. Soc. Exp. Biol.) J. 9:484-496.

37. Ganesan, S., R. Calle, K. Zawalich, K. Greenawalt, W. Zawalich, G.I Shulman, and H. Rasmussen. Immunocytochemical localization of $\alpha$-protein kinase $C$ in rat pancreatic $\beta$-cells during glucose-induced insulin secretion. J. Cell Biol. 119:313-324.

38. Akita, Y., S. Ohno, Y. Konno, A. Yano, and K. Suzuki. 1990. Expression and properties of two distinct classes of the phorbol ester receptor family, four conventional protein kinase $\mathrm{C}$ types, and a novel protein kinase C. J. Biol. Chem. 265:354-362.

39. Knutson, K.L., and M. Hoenig. 1994. Identification and subcellular characterization of protein kinase-C isoforms in insulinoma $\beta$-cells and whole islets. Endocrinology. 135:881-886.

40. Stunff, C.L., and P. Bougneres. 1994. Early changes in postprandial insulin secretion, not in insulin sensitivity, characterize juvenile obesity. Diabetes. 43:696-702.

41. Maffei, M., J. Halaas, E. Ravussin, R.E. Pratley, G.H. Lee, Y. Zhang, H. Fei, S. Kim, R. Lallone, S. Ranganathan, P.A. Kern, and J.M. Friedman. 1995. Leptin levels in human and rodent: Measurement of plasma leptin and ob RNA in obese and weight-reduced subjects. Nat. Med. 1:1155-1161.

42. Considine, R.V., M.K. Sinha, M.L. Heiman, A. Kriauciunas, T.W. Stephens, M.R. Nyce, J.P. Ohannesian, C.C. Marco, L.J. McKee, T.L. Bauer, and J.F. Caro. 1996. Serum immunoreactive-leptin concentrations in normalweight and obese humans. N. Engl. J. Med. 334:292-295.

43. Ravussin, E., R.E. Pratley, M. Maffei, H. Wang, J.M. Friedman, P.H. Bennett, and C. Bogardus. 1997. Relatively low plasma leptin concentrations precede weight gain in Pima Indians. Nat. Med. 3:238-240. 